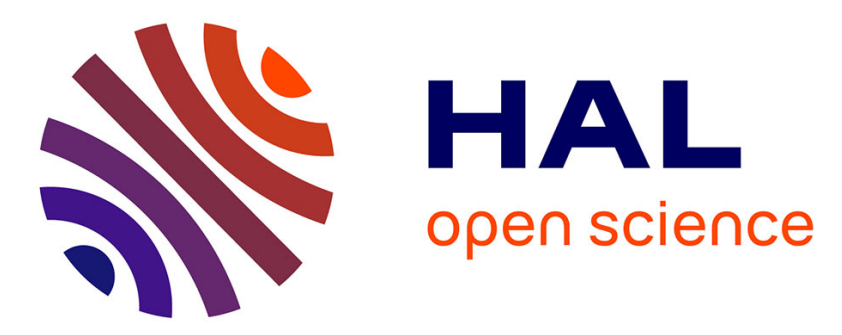

\title{
Atmospheric transport of trace elements toward Antarctica
}

\author{
G. Lambert, B. Ardouin, J. Sanak
}

\section{To cite this version:}

G. Lambert, B. Ardouin, J. Sanak. Atmospheric transport of trace elements toward Antarctica. Tellus B - Chemical and Physical Meteorology, 1990, 42 (1), pp.76-82. 10.1034/j.1600-0889.1990.00009.x . hal-03582282

\section{HAL Id: hal-03582282 \\ https://hal.science/hal-03582282}

Submitted on 21 Feb 2022

HAL is a multi-disciplinary open access archive for the deposit and dissemination of scientific research documents, whether they are published or not. The documents may come from teaching and research institutions in France or abroad, or from public or private research centers.
L'archive ouverte pluridisciplinaire HAL, est destinée au dépôt et à la diffusion de documents scientifiques de niveau recherche, publiés ou non, émanant des établissements d'enseignement et de recherche français ou étrangers, des laboratoires publics ou privés. 


\title{
Atmospheric transport of trace elements toward Antarctica
}

\author{
By G. LAMBERT, B. ARDOUIN and J. SANAK, Centre des Faibles Radioactivités*, \\ Laboratoire mixte CNRS-CEA, F-91198 Gif sur Yvette Cedex, France
}

(Manuscript received 29 November 1988; in final form 5 June 1989)

\begin{abstract}
Since 1960, at the French station of Dumont d'Urville (Terre Adelie coast), during more or less long periods, we have monitored $\mathrm{Rn}-222$ and its decay product $\mathrm{Pb}-210$, fission products due to atmospheric nuclear tests, and the cosmonuclides Be-7 and P-32. Almost all these species show seasonal variations, whose general features are maximum concentrations during the local summer (December-January), and minima in the middle of winter (June-July). A long-term change in the $\mathrm{Pb}-210$ concentrations was also observed at Dumont d'Urville, for all seasons, with a more-or-less continuous decrease since 1969 to 1986 , from 2.5 to $1.5 \mathrm{dpm}$ per $1000 \mathrm{~m}^{3}$. Such variations seem to be quite usual, because an ice core sampled at the South Pole also displays important fluctuations of the $\mathrm{Pb}-210$ concentration in the fresh snow between 1888 and 1974 , from 1 to $3 \mathrm{dpm} / \mathrm{kg}$, particularly from 1920 to 1954 . The latitudinal profiles of both $\mathrm{Rn}-222$ and $\mathrm{Pb}-210$ showing minima between $40^{\circ}$ and $60^{\circ}$ South at sea level, the longrange transport of these nuclides from mid-latitudes toward Antarctica should occur through the higher rather through the lower layers of the troposphere. Therefore, the $\mathrm{Pb}-210$ long-term changes observed can be ascribed to global changes of the general circulation in the Southern hemisphere. The concentrations of $\mathrm{Pb}-210$ at Dumont d'Urville, and the ozone vertical column in October at Halley Bay, show common features, more particularly a significant decrease in the $1980 \mathrm{~s}$, meaning that changes in the atmospheric circulation occurred in the Antarctic area from the middle of the 1970 s, which can partly account for the ozone decrease beside variations of trace species concentrations.
\end{abstract}

\section{Introduction}

The Antarctic continent is probably the only large area on Earth that acts exclusively as a sink for energy, water vapor, and gaseous and particulate trace materials: all these are transported to the Antarctic continent from sources, in regions of lower latitudes. During their long range transport toward and over Antarctica, the chemically active trace species are subjected to their usual removal processes. Moreover, some peculiar processes occur in the very cold Antarctic atmosphere, involving heterogeneous reactions not observed in other terrestrial areas, which have been considered as possible explanations for the so-called ozone hole.

Natural and man-made radioactive tracers are

\footnotetext{
* CFR Contribution no. 1628.
}

very useful for studying these transport processes, because they have well-known sources and, for $\mathrm{Rn}-222$, are evenly spread and almost continuous. Moreover, they do not participate in atmospheric chemical reactions. Rare gases are removed from the atmosphere by their own radioactive decay, and aerosols also by scavenging.

$\mathrm{Rn}-222$ is outgassed from the surface of continents, except Antarctica which is almost totally ice covered. The outgassing rate depends on soil characteristics such as $\mathrm{U} / \mathrm{Ra}$ content, porosity, moisture content and on local meteorological conditions (Tanner, 1980). However, it does not change significantly with time, and a rather constant mean annual value of the $\mathrm{Rn}-222$ atmospheric concentration is observed at continental monitoring stations (Lambert et al., 1982).

$\mathrm{Pb}-210$ aerosols are produced by the radioactive decay of atmospheric $\mathrm{Rn}-222$. $\mathrm{Pb}-210$ 
atoms are trapped by submicron aerosols (Sanak et al., 1981). With the Pb-210 half-life being about 20 years, the main sink of this nuclide is aerosol scavenging, with a global tropospheric mean residence time of about 1 week. However, a $\mathrm{Pb}-210$ reservoir of longer residence time also exists in the stratosphere. A general budget of atmospheric $\mathrm{Rn}-222$ and $\mathrm{Pb}-210$ was made by Lambert et al (1982).

Since 1960, at the French station of Dumont d'Urville, on the Terre Adelie coast (Fig. 1), during more-or-less long periods, beside $\mathrm{Rn}-222$ and its decay product $\mathrm{Pb}-210$, we have monitored fission products due to atmospheric nuclear tests, and the cosmonuclides Be-7 and P-32. The techniques utilized have been described in preceding papers: Lambert (1963) for fission products; Sanak et al. (1985), for cosmonuclides; Lambert et al. (1970) for Rn-222; Lambert et al. (1966, 1975) for Pb-210.
Almost all these species show important seasonal variations, whose general features are maximum concentrations during the local summer (December-January), and minima in the middle of winter (June-July). It is worthy of note that the major errors of measurement are due to stochastic variations in radioactive countings. In this paper, we only use mean monthly, seasonal and annual values, calculated from at least 30 measurements, and sometimes thousands. The statistical errors are therefore significantly reduced to less than a few $\%$, and generally still less. They can be totally neglected relative to the variations under study. By contrast, non-stochastic errors are mainly due to inaccurate calibrations, particularly of the radioactive counter efficiency: these errors obviously do not compensate by averaging, and they forbid a precise study of the long term evolution of most of the species, but $\mathrm{Pb}-210$.

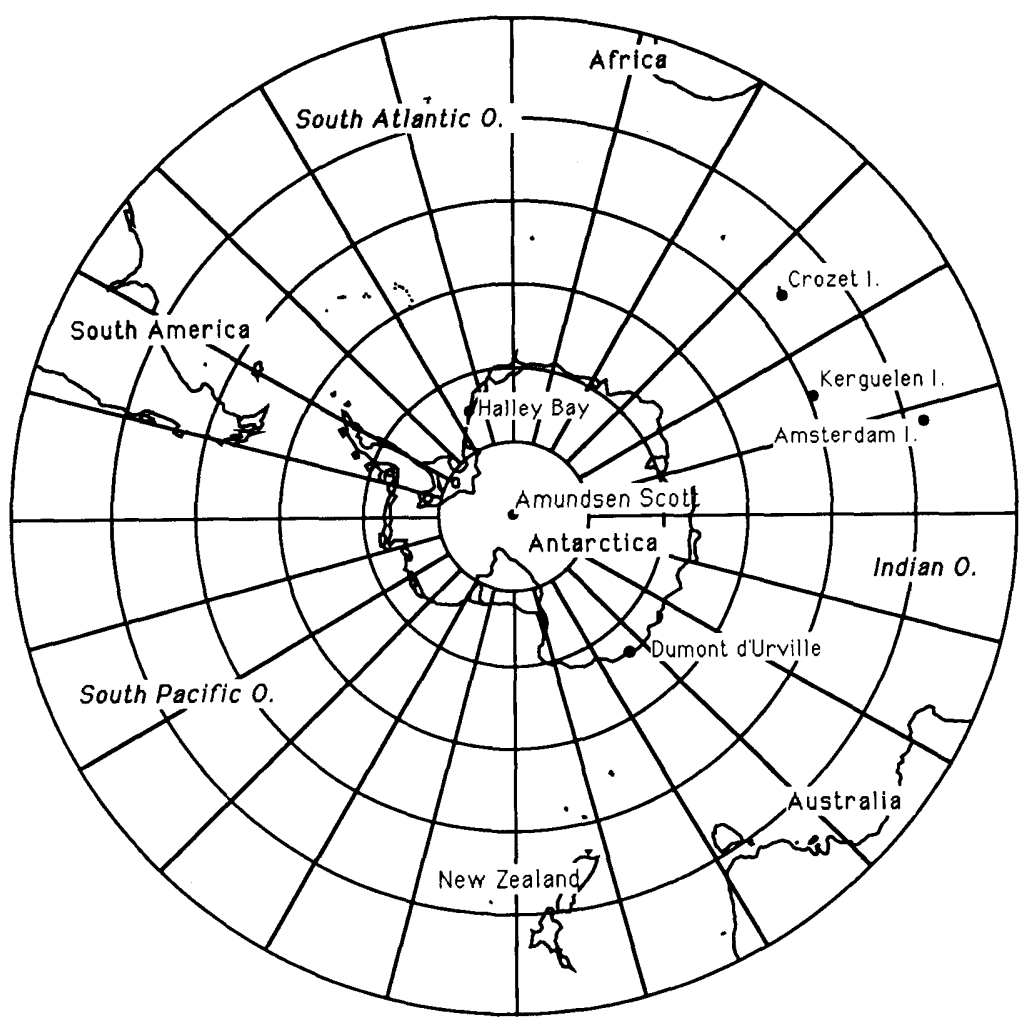

Fig. 1. Antarctic map.

Tellus 42B (1990), 1 


\section{Seasonal variations of $\mathbf{R n - 2 2 2}$ and $\mathbf{P b}-\mathbf{2 1 0}$}

$\mathrm{Rn}-222$ atmospheric concentrations in subantarctic and antarctic areas are controlled by their long-range transport from mid latitudes, which varies with the season. This nuclide has been monitored from 1965 to the present at Kerguelen island, and from 1967 to 1981 at Dumont d'Urville, at the rate of 12 times per day. Fig. 2 shows its seasonal variations at Dumont d'Urville, each figure being calculated from about 5000 values. During the same time, $\mathrm{Pb}-210$ has also been monitored at Dumont d'Urville on a daily basis. Its seasonal variations are shown in the same figure, where each point represents about 400 values. The similarity of the two curves is particularly remarkable, suggesting that the residence times of the two nuclides are extremely close to each other over the subantarctic ocean, namely 5.5 days, which is the $\mathrm{Rn}-222$ radioactive mean life, instead of 1 week for the whole troposphere.

This rather short life suggests that the transport of these nuclides from their remote continental sources is rapid. However, Sanak (1983) and Polian et al. (1986) pointed out that in summer, at sea level, the latitudinal profiles of both $\mathrm{Rn}-222$ and $\mathrm{Pb}-210$ show minima between $40^{\circ}$ and $60^{\circ}$ South. This observation applies particularly to $\mathrm{Pb}-210$, as shown in Fig. 3, in which we have gathered the results obtained by several authors for subantarctic traverses along different meridians, as well as the US network at $80^{\circ}$ West,

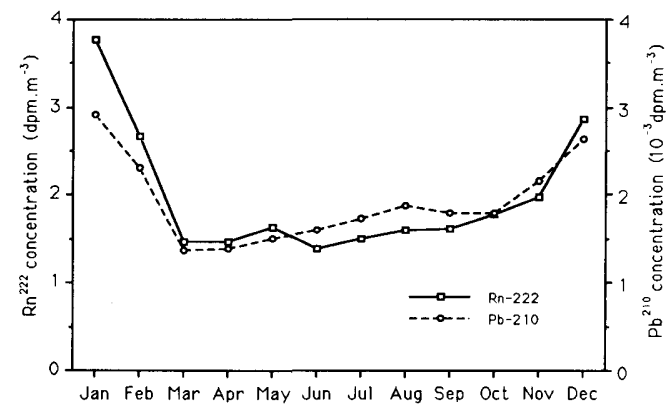

Fig. 2. Seasonal variations of $\mathrm{Rn}-222$ and $\mathrm{Pb}-210$ at Dumont d'Urville (Terre Adelie) for the period 19671981. Each point has been calculated from about 5000 values of $R n-222$, and 400 values of $P b-210$. operating from 1974 to 1976 . It is worthy to note that the figure relative to Dumont d'Urville is the mean value of the 4 summer months (November to February), from 1960 to 1980 , i.e., of about 1200 values.

Consequently, during the summer, the longrange transport of these nuclides from mid-latitudes toward Antarctica cannot occur through the lower layers of the troposphere. On the other hand, a stratospheric circulation is ruled out by the long time involved. For all these reasons, Polian (1984) concluded that there is a transport of $\mathrm{Rn}-222$ and $\mathrm{Pb}-210$ through the higher layers of the troposphere.

\section{Seasonal variations of fission products and cosmonuclides}

The preceding hypothesis is supported by the study of the atmospheric concentrations of fission products at Dumont d'Urville, which show a clear maximum in summer, especially in February (Fig. 4). During the periods free of nuclear tests, the fission products collected at ground level have been injected into the higher troposphere from their stratospheric reservoir. Lambert et al. $(1965,1966)$ showed that the geographical distribution of the fission products was then similar to that of $\mathrm{Rn}-222$ and $\mathrm{Pb}-210$, with a minimum at around $50^{\circ}$ South.

The very important role played by transport through the high troposphere in the observed seasonal variations is emphasized by analysis of the short-lived cosmonuclides Be-7 (53.4 days) and P-32 (14.3 days). These nuclides are mainly produced in the stratosphere (Lal and Peters, 1962 ) at a very constant ratio $\mathrm{Be}-7 / \mathrm{P}-32=100$. It may be observed in Fig. 5 that the longer-lived of these nuclides has an almost constant mean monthly value, whereas the shorter-lived one, whose concentration at ground level strongly depends on its recent injection from the stratosphere, shows the same already-mentioned seasonal variations.

Therefore, the similarity of the seasonal variations at Dumont d'Urville of $\mathrm{Rn}-222, \mathrm{~Pb}-$ 210 , fission products and short-lived cosmonuclides can be simply ascribed to the wellknown fact that, at spring time (around October), 

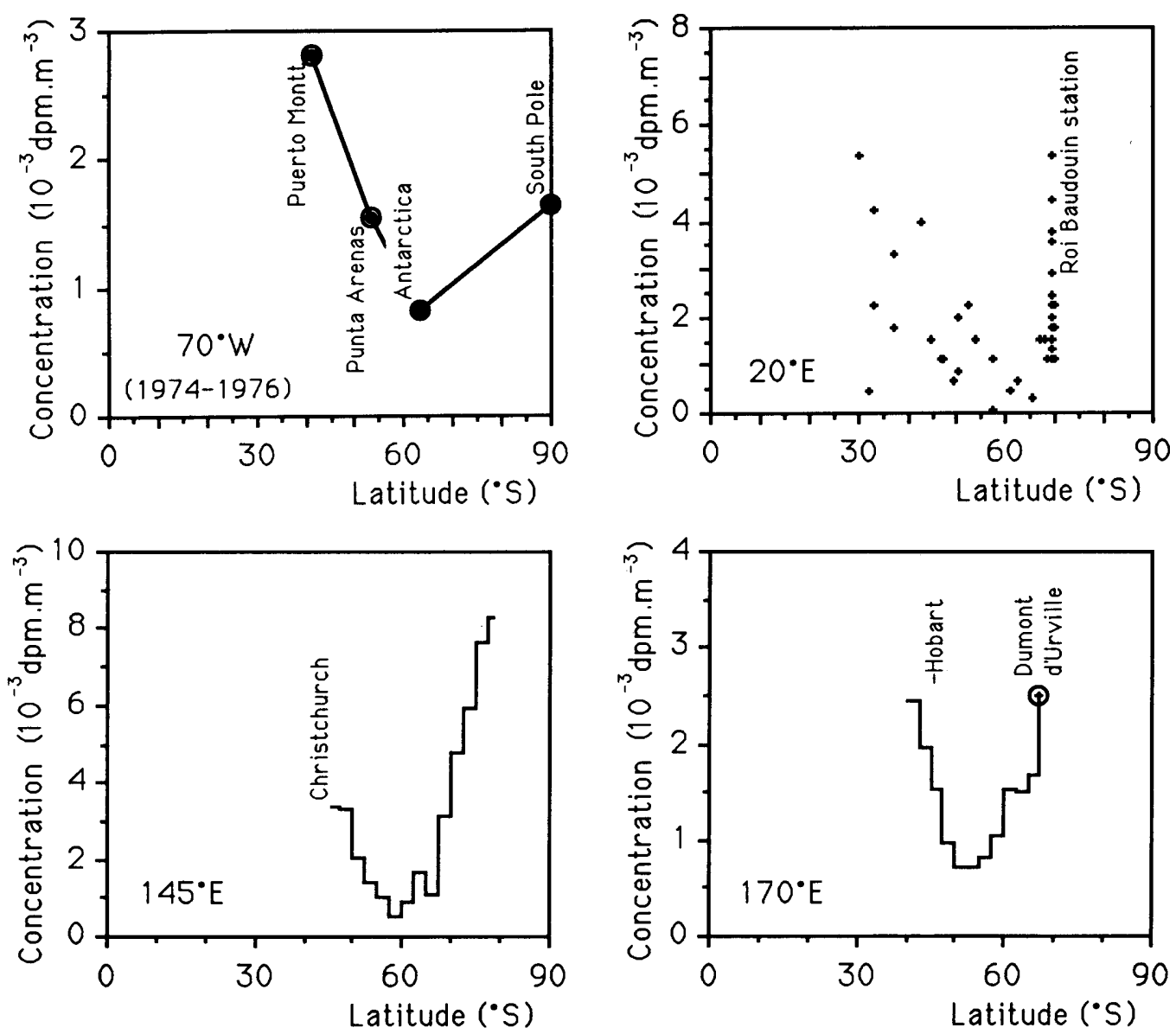

Fig. 3. Latitudinal profiles of $\mathrm{Pb}-210$ in Subantarctic areas along the meridians $70^{\circ} \mathrm{W}, 20^{\circ} \mathrm{E}, 145^{\circ} \mathrm{E}$ and $170^{\circ} \mathrm{E}$. Large circles represent the average of a large number of measurements.

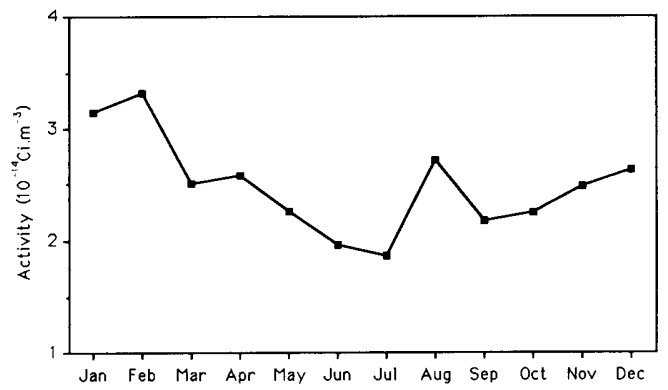

Fig. 4. Seasonal variations at Dumont d'Urville of fission products from stratospheric origin, i.e., during periods without atmospheric nuclear tests.

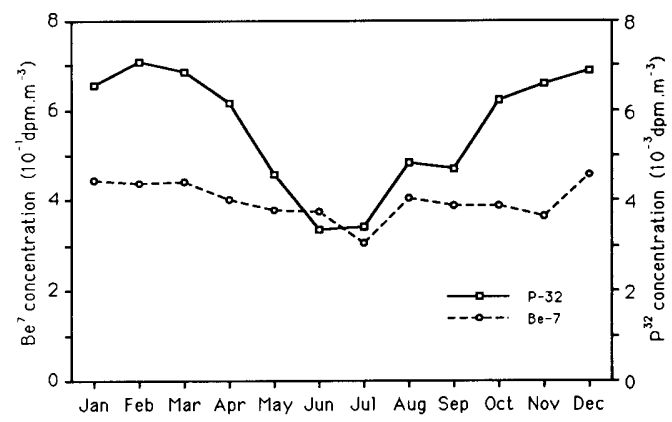

Fig. 5. Seasonal variations of Be-7 and P-32 at Dumont d'Urville for the period 1977-1981. Each point represents 100 to 150 values. 
when the winter polar vortex vanishes, the whole Antarctic atmosphere is overturned by air advections from the north.

\section{Long-term variations of $\mathbf{P b}-\mathbf{2 1 0}$}

Our Be-7 and P-32 monitoring at Dumont d'Urville has been too short to enable a long term trend study. A similar study would be unsound for atmospheric fission products whose variations are primarily due to the nuclear test history.

As above mentioned, $\mathrm{Rn}-222$ has been monitored from 1965 to the present at Kerguelen island, and from 1967 to 1982 at Dumont d'Urville. However the interannual calibration of the measurement devices is not very accurate. Nevertheless, it may be seen in Fig. 6 that, at these stations, the $\mathrm{Rn}-222$ mean annual values are almost constant, within $\pm 25 \%$, which is about the same as the long-term reproducibility. Consequently, these observations cannot be interpreted in terms of atmospheric circulation changes.

$\mathrm{Pb}-210$ has also been monitored at Dumont d'Urville since 1960 , on a daily basis. In fact, the aerosols are only collected at this station, by filtration, and the filters are subsequently measured in the laboratory after their return to France. The $\mathrm{Pb}-210$ activity is determined through that of its granddaughter Po-210, which is an alpha emitter with a 138 day half-life. For this reason, and because the Po- 210 activity is typically 10 times less than that of $\mathrm{Pb}-210$ in the troposphere, a two-year delay is necessary to $:^{+}$

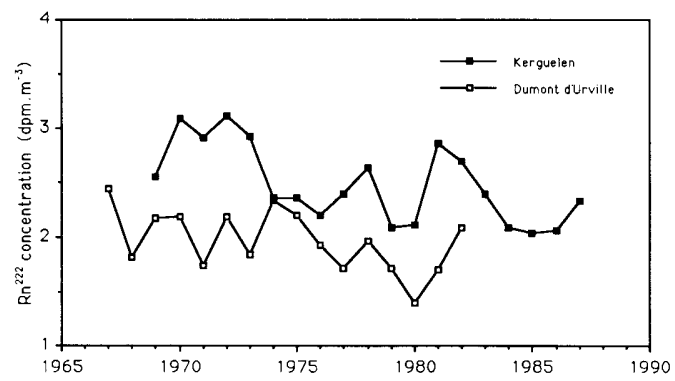

Fig. 6. Long-term monitoring of $\mathrm{Rn}-222$ at Kerguelen island and Dumont d'Urville. Each point represents about 4000 measurements; however, the interannual calibration is not better than $\pm 25 \%$.
Po-210 reach its radioactive equilibrium with $\mathrm{Pb}-210$ on the filter. Therefore, the measurements relative to 1987 are not already available.

Owing to the utilized technique, the efficiency of the measurements was continuously controlled by regularly remeasuring several filters. No shift was detected in this efficiency (Lambert et al. 1988). Consequently, long term variations of the order of a few $\%$ can be considered as significant.

A record of the mean annual concentrations is shown in Fig. 7, where each point represents the mean value of about 365 daily measurements, together with the values relative to DecemberFebruary (seasonal maximum) and May-August (seasonal minimum), where each point is the mean value of about 100 measurements. Except in 1964 and 1967, these curves show the same general trend, characterized by a more-or-less continuous decrease since 1969 , from 2.5 to 1.5 $\mathrm{dpm}$ per $1000 \mathrm{~m}^{3}$ for the mean annual value. Therefore, the long-term change in the $\mathrm{Pb}-210$ concentrations at Dumont d'Urville, observed for all seasons, should be due to a global change of the general circulation in the Southern hemisphere.

Such variations seem to have been quite usual in the past. In effect, an analysis of an ice core, sampled at South Pole, also displayed important fluctuations of the $\mathrm{Pb}-210$ concentration in the fresh snow between 1888 and 1974, from 1 to $3 \mathrm{dpm} / \mathrm{kg}$ (Sanak and Lambert, 1977). A large change of the $\mathrm{Pb}-210$ concentration was observed in the Antarctic snow, particularly from 1920 to 1954: it could therefore be possible that similar

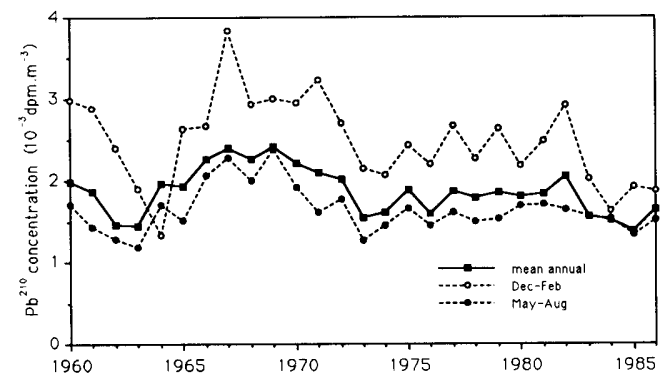

Fig. 7. Long-term monitoring of $\mathrm{Pb}-210$ at Dumont d'Urville: mean values annual, December to February, and May to August calculated from daily measurements. 
atmospheric circulation changes already occurred in the past, even though they were not detected through classical meteorological measurements. They cannot be explained for the moment.

\section{Comparison of $\mathrm{Pb}-210$ and other trace species}

It is interesting to examine to what extent the preceding changes have affected other natural and/or man made species, whether chemically inactive like $\mathrm{Pb}-210$ aerosols, or active such as ozone. This gas is likely (beside $\mathrm{Pb}-210$ ) the only chemical species for which a long-term record is available in the Antarctic atmosphere.

Farman et al. (1985), and Stolarski et al. (1986), showed a remarkable downward trend of the ozone vertical column during the springtime over Antarctica. It is generally accepted that ozone variations are controlled by photochemical processes, and by the atmospheric circulation that is driven by a particularly stable winter polar vortex. Most models of this phenomenon have focused on chemical interactions of ozone with natural and/or anthropogenic trace species (Solomon et al., 1986; McElroy et al., 1986a, b; Crutzen and Arnold, 1986; Molina et al., 1987), although dynamical processes have also been considered (Tung et al., 1986).

However, the atmospheric concentrations of $\mathrm{Pb}-210$ do not depend on chemical processes, and their record in Antarctica, since 1960, also shows a clear decrease since 1979. This trend seems to

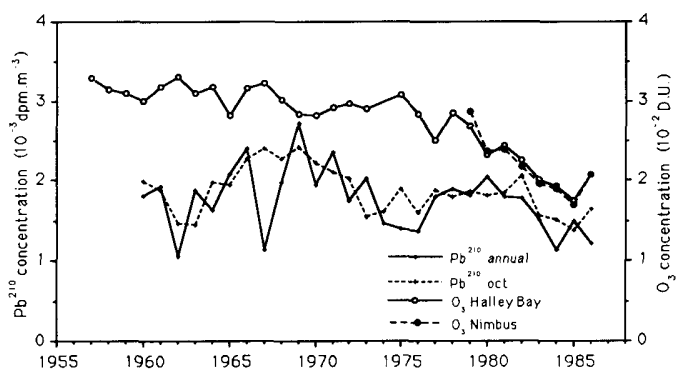

Fig. 8. Comparison of ozone and $\mathrm{Pb}-210$ in Antarctica. be rather similar to that of ozone. The concentrations of $\mathrm{Pb}-210$ at Dumont d'Urville, relative to October, are reported in Fig. 8, together with the ozone vertical column measured during the same months at Halley Bay (Farman et al., 1985), which is also situated on the Antarctic coast, but at a longitude almost diametrically opposed to Dumont d'Urville. We plot in the same figure the ozone measurements deduced from the Nimbus-7 satellite observations (Stolarski, 1988). All these curves show common features, more particularly a significant decrease in the $1980 \mathrm{~s}$, but the correlation coefficients are small: -0.66 (confidence level $99.2 \%$ ) for 1960-1975; + 0.71 (confidence level $97.8 \%$ ) for 1977-1986. All correlations are considerably weakened when data relative to 1976 are also utilized, the correlation coefficients falling to -0.49 and +0.41 , respectively.

To conclude, it seems that a drastic change occurred during the period 1975-1977 in the mean meridional transport of trace materials from mid-latitudes to the Antarctic atmosphere. A similar observation can be made from the Be-7 record in aerosols at the South Pole and Punta Arenas (Feely et al., 1988), where the year 1976 seems to be unusual, more particularly in October. This change is also visible in the chemical analyses of Antarctic ice cores by Legrand and Kirchner (1988). All these observations mean that, beside variations of trace species concentrations, which can account for a local as well as general ozone decrease (Bowman, 1988; Reinsel et al., 1988), changes in the atmospheric circulation also occurred in the Antarctic area, from the middle of the 1970s, i.e., before the ozone decrease became important.

\section{Acknowledgements}

This research was supported by the French CNRS, CEA, the administration of Terres Australes et Antarctiques Françaises, and the Expéditions Polaires Françaises. The authors thank all scientists and technicians for aerosol sampling in Antarctica, and J. C. Duplessy for fruitful discussions. 


\section{REFERENCES}

Bowman, K. P. 1988. Global trends in total ozone. Science 239, 48-50.

Crutzen, P. J. and Arnold, F. 1986. Nitric acid cloud formation in the cold Antarctic stratosphere: a major cause for the springtime "ozone hole". Nature 324, $651-655$.

Farman, J. C., Gardiner, B. G. and Shanklin, J. D. 1985. Large losses of total ozone in Antarctica reveal seasonal ClOx/NOx interaction. Nature 315, 207-210.

Feely, H. W., Larsen, R. J. and Sanderson, C. G. 1988. Factors that cause seasonal variations in Be-7 concentrations in surface air. E.M.L. 497, 91-165.

Lal, D. and Peters, B. 1962. Cosmic ray produced isotopes and their application to problems in geophysics. In Progress in cosmic ray physics and elementary particle physics, 6, Amsterdam: North Holland Publ., 1-74.

Lambert, G. 1963. Etude du comportement des aerosols radioactifs artificiels; application à quelques problèmes de circulation atmosphérique (Artificial radioactive aerosols study, applied to atmospheric circulation problems). Thesis, University of Paris. Rapport C.E.A. R2347.

Lambert, G., Labeyrie, J. and Ardouin, B. 1965. Sur l'existence d'une structure zonale de la basse atmosphère, principalement dans l'hémisphère Sud. (Zonal structure of the lower atmosphere, mainly in the Southern hemisphere) C. R. Acad. Sci. 261, 38573860.

Lambert, G., Ardouin, B., Nezami, M. and Polian, G. 1966. Possibilities of using lead 210 as an atmospheric tracer. Tellus $18,421-426$.

Lambert, G., Polian, G. and Taupin, D. 1970. Existence of periodicity in radon concentrations and in the large-scale circulation at lower altitudes between $40^{\circ}$ and $70^{\circ}$ south. J. Geophys. Res. 75, 2341-2345.

Lambert, G., Ardouin, B., Polian, G. and Sanak, J. 1975. Natural radioactivity balance in the atmosphere of the Southern Hemisphere. The Natural Radiation Environment 2, conf-720805 P2 (United States Energy Research and Development Administration. Office of Public Affairs/Technical Information Center).

Lambert, G., Polian, G., Sanak, J., Ardouin, B., Buisson, A., Jegou, A. and Le Roulley, J-C. 1982. Cycle du radon et de ses descendants: application à l'étude des échanges troposphère stratosphère (Radon and decay products cycle: application to the troposphere stratosphere exchanges). Annales de Géophysique $38,497-531$.

Lambert, G., Ardouin, B., Polian, G. and Sanak, J. 1988. Le plomb 210 dans les régions Antarctiques et Subantarctiques (Lead-210 in Antarctic and Subantarctic regions). Actes du colloq. sur la Rech. Franç. dans les Terres Australes, C.N.F.R.A. ed.

Legrand, M. and Kirchner, S. 1988. Polar atmospheric circulation and chemistry of recent (1957-1983) south polar precipitations. Geophys. Res. Lett. 15, 879-882.

McElroy, M. B., Salawitch, R. J., Wofsy, S. C. and Logan, J. A. 1986a. Antarctic ozone: reductions due to synergistic interactions of chlorine and bromine. Nature 321, 759-762.

McElroy, M. B., Salawitch, R. J. and Wofsy, S. C. 1986b. Antarctic ozone: chemical mechanisms for the spring decrease. Geophys. Res. Lett. 13, 12961299.

Molina, M. J., Tsot, L., Molina, L. T. and Wang, F. C. Y. 1987. Antarctic stratospheric chemistry of chlorine nitrate, hydrogene chloride, and ice: release of active chlorine. Science 238, 1253-1257.

Polian, G. 1984. Radioactivité naturelle atmosphérique dans l'hémisphère sud (Natural radioactivity of the atmosphere in the Southern hemisphere) Thesis, Université Paris VI.

Polian, G., Lambert, G., Ardouin, B. and Jegou, A. 1986. Long-range transport of continental radon in Subantarctic areas. Tellus 38B, 178-189.

Reinsel, G. C., Tiao, G. C., Ahn, S. K., Pugh, M., Basu, S., De Luisi, J. J., Mateer, C. L., Miller, A. J., Connell, P. S. and Wuebles, D. J. 1988. An analysis of the 7-year record of SBUV satellite ozone data: global profile features and trends in total ozone. $J$. Geoph. Res. 93, 1689-1703.

Sanak, J. 1983. Recherches sur l'origine et les modes de transport des aerosols présents en Antarctique (Origin and transport processes of the aerosols present in Antarctica). Thesis, Université de Picardie, St. Quentin.

Sanak, J. and Lambert, G. 1977 . Lead 210 or climatic changes at South Pole? Geophys. Res. Lett. 4, 357359.

Sanak, J., Gaudry, A. and Lambert, G. 1981. Size distribution of $210 \mathrm{~Pb}$ aerosols over oceans. Geophys. Res. Lett. 8, 1067-1069.

Sanak, J., Lambert, G. and Ardouin, B. 1985. Measurement of stratosphere to troposphere exchanges in Antarctica by using short-lived cosmonuclides. Tellus $37 B, 109-115$.

Solomon, S., Garcia, R. R., Rowland, F. S. and Wuebles, D. J. 1986. On the depletion of Antarctic ozone. Nature 321, 755-758.

Stolarski, R. S., Kreuger, A. J., Schoeberl, M. R., McPeters, R. D., Newman, P. A. and Alpert, J. C. 1986. Nimbus-7 satellite measurements of the springtime ozone decrease. Nature $322,808-811$.

Stolarski, R. S. 1988. The Antarctic ozone hole. Scient. American 258, 20-26.

Tanner, A. B. 1980. Natural Radiation Environment III. U.S. Dept. of Energy, CONF-780422.

Tung, K. K., Ko, M. K. W., Rodriguez, J. M. and Sze, N. D. 1986. Are Antarctic variations a manifestation of dynamics or chemistry?. Nature $322,811-814$. 